\title{
A Bandpass Frequency Selective Surface Filter for Earth Observation Satellite and Radar Applications
}

\author{
Olcay ALTINTAŞ ${ }^{* 1}$ ORCID 0000-0003-3237-4392 \\ ${ }^{1}$ Iskenderun Technical University, Faculty of Engineering and Natural Science, Department of \\ Electrical and Electronics Engineering, Iskenderun/Hatay
}

Geliş tarihi: 09.07.2021～Kabul tarihi: 10.12.2021

Attf şekli/ How to cite: ALTINTAŞ, O., (2021). A Bandpass Frequency Selective Surface Filter for Earth Observation Satellite and Radar Applications. Çukurova Üniversitesi, Mühendislik Fakültesi Dergisi, 36(4), 1033-1040.

\begin{abstract}
In this paper, a bandpass frequency selective surface filter has been suggested for the satellite and radar applications at $\mathrm{X}$ band frequency regime. The study has been conducted both numerically and experimentally in a wide range frequency band between $2 \mathrm{GHz}$ and $14 \mathrm{GHz} .2 \mathrm{GHz}$ of $3 \mathrm{~dB}$ bandwidth between $7.3 \mathrm{GHz}$ and $9.3 \mathrm{GHz}$ has been obtained. The proposed structure has the polarization insensitive characteristic. It also has angular stability with the incident angle ranges from $0^{\circ}$ to $60^{\circ}$ with very small frequency deviations both TE and TM polarization modes. The prototype of the FSS structure is composed of 20x20 unit cells in a dimension of $18 \mathrm{~cm}$ x $18 \mathrm{~cm}$. The experimental studies have been conducted by using Agilent PNA-L vector network analyzer with two horn antennas. The bandpass filter can be effectively used in many satellite and radar systems as an antenna radome to prevent noises and to reject unwanted frequency bands
\end{abstract}

Keywords: FSS, Bandpass filter, Satellite, Radar

\section{Yer Gözlem Uydusu ve Radar Uygulamaları için Bant Geçiren Frekans Seçici Yüzey Filtresi}

$\ddot{\mathbf{O} z}$

$\mathrm{Bu}$ makalede, $\mathrm{X}$ bant frekans rejiminde uydu ve radar uygulamaları için bir bant geçiren frekans seçici yüzey filtresi önerilmiştir. Çalışma $2 \mathrm{GHz}$ ile $14 \mathrm{GHz}$ arasındaki geniş bir frekans bandında hem sayısal hem de deneysel olarak gerçekleştirilmiştir. $7.3 \mathrm{GHz}$ ile $9.3 \mathrm{GHz}$ arasında $2 \mathrm{GHz} 3 \mathrm{~dB}$ bant genişliği elde edilmiştir. Önerilen yapı polarizasyona duyarsız özelliğe sahiptir. Ayrıca, hem TE hem de TM polarizasyon modlarında çok küçük frekans sapmaları ile $0^{\circ}$ ila $60^{\circ}$ arası geliş açısı aralıklarıyla açısal kararlılığa sahiptir. FSS yapısının prototipi $18 \mathrm{~cm} \times 18 \mathrm{~cm}$ boyutlarında $20 \times 20$ birim hücrelerden oluşmaktadır. Deneysel çalışmalar Agilent PNA-L vektör ağ analizörü ve iki huni anten kullanılarak

\footnotetext{
*Sorumlu yazar (Corresponding author): Olcay ALTINTAŞ, olcay.altintas@iste.edu.tr
} 
gerçekleştirilmiştir. Bant geçiren filtre, gürültüleri önlemek ve istenmeyen frekans bantlarını reddetmek için bir anten radomu olarak birçok uydu ve radar sisteminde etkin bir şekilde kullanılabilir.

Anahtar Kelimeler: FSS, Bant geçiren filtre, Uydu, Radar

\section{INTRODUCTION}

The satellite and radar technologies have been of strategic importance for many research respects such as military, aviation, weather forecast, and even extraterrestrial. Observation radars and research satellites have been especially need advance antenna systems to explore the environment at the best possible standard. In this perspective, the antenna performance can be increased by using different technical solutions to eliminate or to filter the noise and unexpected incident waves. The metamaterials (MTMs), electromagnetic band gap structures (EBGs), high impedance surfaces (HISs), frequency selective surfaces (FSSs) can be listed as some methods to manipulate electromagnetic waves. Among this methods, FSS structures are strongly improved as band pass [1-5] or band stop filters [6-7] in a wide range frequency bands.

Researchers have suggested the FSS structures in various satellite and earth observation radar applications in microwave and terahertz regimes. Morrow et al. have studied a low profile FSS structure for radar earth observation. The unit cell of the proposed FSS structure have consist of dual circular loop and it performs at $\mathrm{X}$ band frequency regime [8]. Deng et al. have proposed a quad-band reflect array antenna for $\mathrm{Ku} / \mathrm{Ka}$ band satellite communication applications. The reflect array antenna is operated at the frequencies of $12.5 \mathrm{GHz}$, 14.25 GHz, $20.4 \mathrm{GHz}$ and $30.2 \mathrm{GHz}$ with the aperture efficiencies of $45.6 \%, 44 \%, 56 \%$ and $54.8 \%$, respectively [9]. Smith et al. have suggested an L- and Ka-band satellite communication antenna with an FSS-backed circularly polarized reflect array. The operating frequencies of the shared aperture antenna are $1575 \mathrm{MHz}, 20 \mathrm{GHz}$ and $30 \mathrm{GHz}$ [10]. Ferraro et al. have investigated incident angle and polarization dependent characteristics of a cross shaped FSS terahertz filter. The proposed structure have been a good candidate for terahertz filter or sensing applications [11]. Euler et al. have improved a FSS based split slot ring shaped liner to circular polarization converter. This submilimeter wave transmission polarizer have achieved $11.75 \%$ of $3 \mathrm{~dB}$ axial ratio bandwidth between $300 \mathrm{GHz}$ and $340 \mathrm{GHz}$ [12]. Machado et al. proposed an ultra-thin FSS absorber structures for spacecraft thermal blanket. Five different absorber designs have constructed using polyethylene terephthalate (PET) material with the 140 micron thickness. The optimum operating frequency of the hexagonal patch array based FSS absorbers is around $10 \mathrm{GHz}$ [13]. Dickie et al. have discussed a FSS design and fabrication difficulty for future space science technology at millimeter to submillimeter wave wavelength. They have offered a new reconfigurable FSS with piezoelectric actuators which provide high frequency dynamic switch at $275 \mathrm{GHz}$ [14]. Poojali et al. have examined the factors which influence the performance of an FSS structure in microwave regime. The structure have exhibited polarization independent and angle stability characteristics with low loss on a dielectric substrate for atmospheric remote sensing [15].

In this study, a complementary fractal loop bandpass FSS filter have been achieved at the operating frequencies of earth observation satellites and their downlinks which covers the frequency ranges between $7.5 \mathrm{GHz}$ and $9 \mathrm{GHz}$. The study have been realized both numerically and experimentally at the frequencies between $2 \mathrm{GHz}$ and $14 \mathrm{GHz}$. The evolution phases during the design process has been examined and the parametric study is realized to determine exact operating frequency of the proposed filter. The polarization and incident angle dependences of the bandpass FSS filter have been also investigated both numerically and experimentally. The numerical studies have been conducted by using a commercial, finite integration technique (FIT) based full wave solver. The experimental studies have been performed by using Agilent PNA-L 
vector network analyzer (VNA) having a working frequency between $10 \mathrm{MHz}$ and $43.5 \mathrm{GHz}$. Also, two horn antennas operates between $3 \mathrm{GHz}$ and $18 \mathrm{GHz}$ have been used during the experimental works. The proposed bandpass FSS filter is rejected L-S- and $\mathrm{X}$ - band except for a $3 \mathrm{~dB}$ frequency band between $7.3 \mathrm{GHz}$ and $9.3 \mathrm{GHz}$. It is a good bandpass filter candidate for earth observation satellite and radar applications.

\section{GEOMETRY DESIGN OF THE FSS STRUCTURE}

The FSS structure is consist of periodically adjusted unit cells. The FR4 type material with a thickness of $1.6 \mathrm{~mm}$ and a dielectric constant of 4.3 is chosen as substrate layer. Perfect electric conductor (PEC) is selected as metallic layer. The unit cell dimension of the FSS structure is $9 \mathrm{~mm} \mathrm{x}$ $9 \mathrm{~mm}$. Unit cell boundary conditions have been arrange along $\mathrm{x}^{-}$and $\mathrm{y}$ - directions to calculate $S$ - parameters in periodic aspect.

The geometry design of the proposed structure is divided into four sections as shown in Figure 1. In Figure 1(a), the square patch (SP) has been created with an edge length parameter 'edge'. This capacitive surface act as a narrow bandpass filter at the frequency range between $2 \mathrm{GHz}$ and $14 \mathrm{GHz}$ as shown in Figure 2. After that the fractal patch (FP) has been obtained by subtracting quarter circle at each corner of the square patch as demonstrated in Figure 1(b). The circle radius parameter is called 'outr' and the fractal patch is also exhibit a capacitive surface characteristics. In the third phase of geometry design, fractal loop (FL) with a line thickness parameter ' $w$ ' has been carved out as illustrated in Figure 1(c). In this phase, the band stop filter behavior has been observed at the operating frequency range as shown in Figure 2, since the fractal loop geometry has the characteristics of inductive surface. Finally, the complementary fractal loop (CFL) shape FSS structure has been created in Figure 1(d) to obtain a certain bandpass frequency range at operating band. The parameter values of edge, outr and $\mathrm{w}$ has been determined as $7.8 \mathrm{~mm}, 3.6 \mathrm{~mm}$ and
$0.2 \mathrm{~mm}$, respectively. The $3 \mathrm{~dB}$ operating frequency band of CFL shaped FSS structure is between $7.3 \mathrm{GHz}$ to $9.3 \mathrm{GHz}$ as shown in Figure 2 .
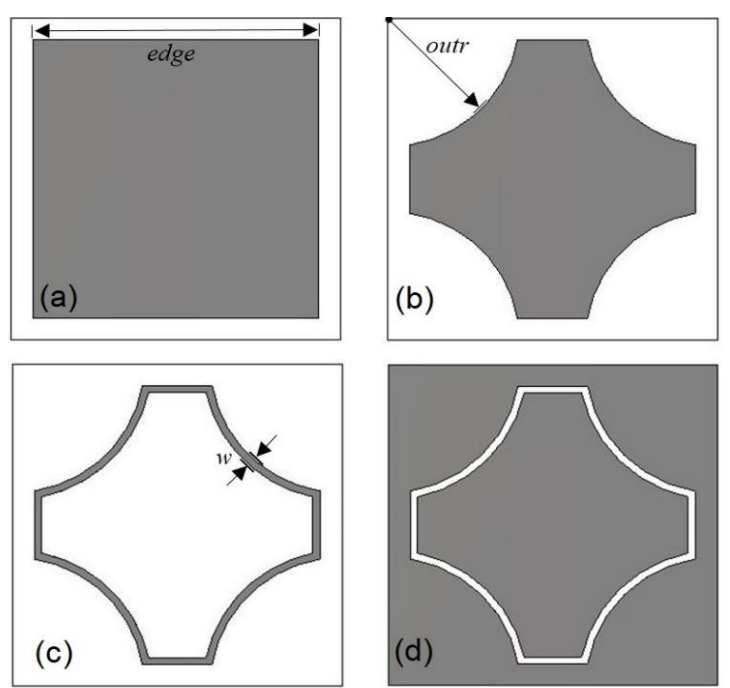

Figure 1. The geometry design sections of the proposed structure; (a) SP, (b) FP, (c) FL and (d) CFL

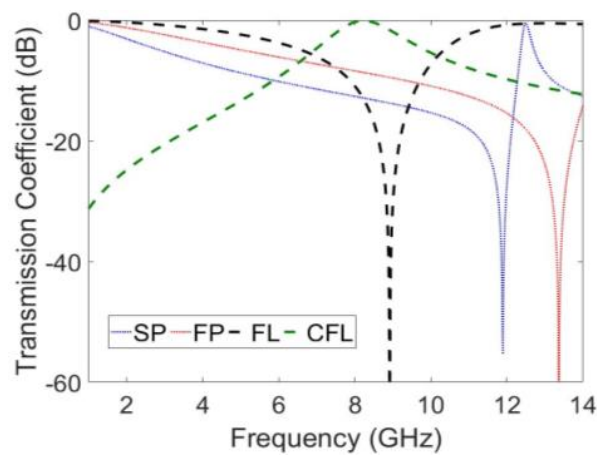

Figure 2. Transmission coefficients of the geometry design section of the proposed structure

\section{NUMERICAL STUDIES}

The numerical studies of the proposed bandpass FSS filter have been conducted by using a FIT based simulation software at the frequency range between $2 \mathrm{GHz}$ and $14 \mathrm{GHz}$. The parametric studies, polarization and incident angle sensitivity have been investigated in this section. 

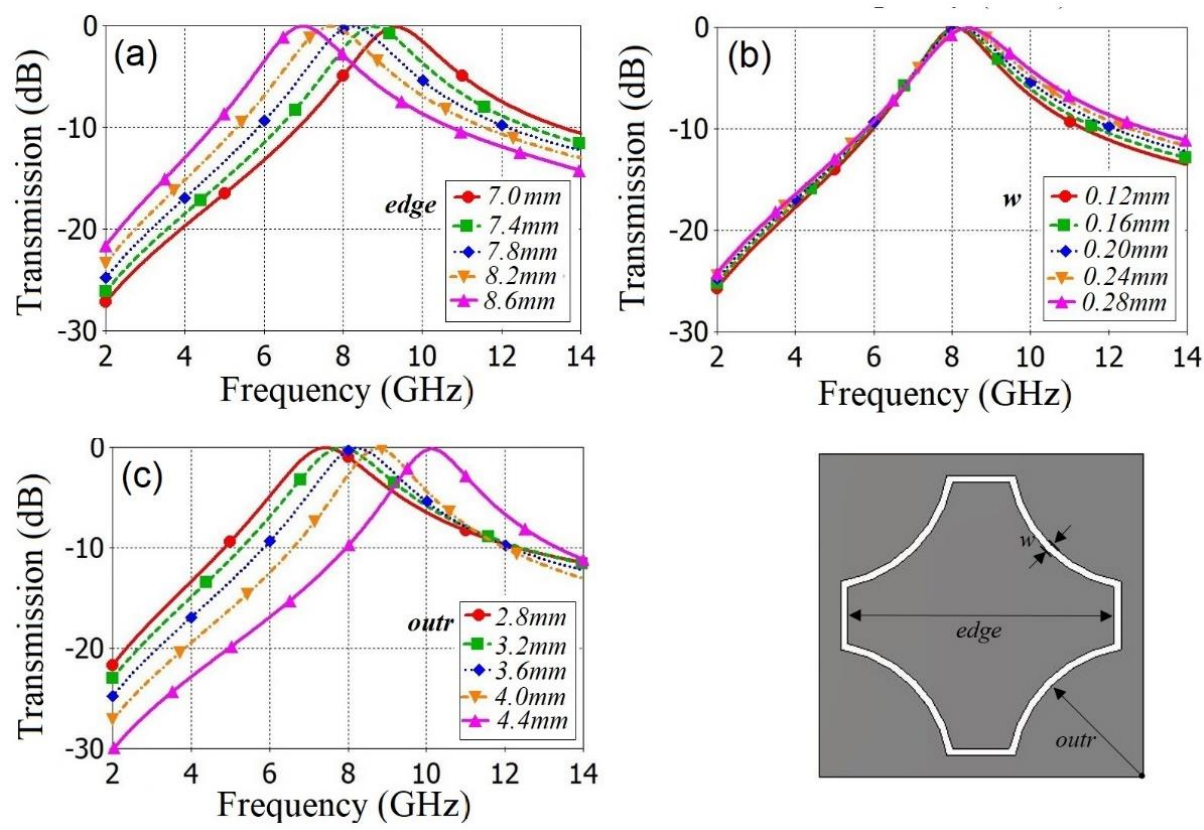

Figure 3. Parametric studies of the proposed structure; (a) edge, (b) w and (c) outr

The edge length parameter 'edge' is studied between $7.0 \mathrm{~mm}$ and the $8.6 \mathrm{~mm}$ by increasing $0.4 \mathrm{~mm}$ at each step. The maximum transmission frequency point is linearly decreased with rising the value of the edge as illustrated in Figure 3(a). This variation is explained with increasing the overall capacitive value of the proposed FSS structure. Secondly, the line thickness parameter ' $\mathrm{w}$ ' is examined between $0.12 \mathrm{~mm}$ and $0.28 \mathrm{~mm}$ by varying $0.04 \mathrm{~mm}$ at each step. The slight changes have been observed in the maximum transmission frequency point while the thickness parameter changes in narrow scale as demonstrated in Figure 3(b). Finally, the circle radius parameter 'outr' has been observed between $2.8 \mathrm{~mm}$ and $4.4 \mathrm{~mm}$ by changing $0.4 \mathrm{~mm}$ at each step. The maximum transmission frequency point is decreasingly shifted by reducing the parameter outr as shown in Figure 3(c). The parameter values of the proposed band pass filter structure have been selected as $7.8 \mathrm{~mm}, 3.6 \mathrm{~mm}$ and $0.2 \mathrm{~mm}$ for edge, outr and w. Hence, the operating frequency band of structure (between $7.3 \mathrm{GHz}$ and $9.3 \mathrm{GHz}$ ) with these parameter values covers the working frequency ranges of the earth observation satellites and their downlinks at L- and X-bands.
The transmission band result of the filter are numerically observed for TE and TM polarization condition under normal incident angle as plotted in Figure 4. The transmission response is obtained as the same results for both polarization. The transmission bandwidth values are given as the percentile ratio of $3 \mathrm{~dB}$ bandwidth to of the central frequency of operating band. The $3 \mathrm{~dB}$ bandwidth has been obtained $23.8 \%$ for both polarizations. It is concluded that the proposed structure exhibits polarization insensitive characteristic.

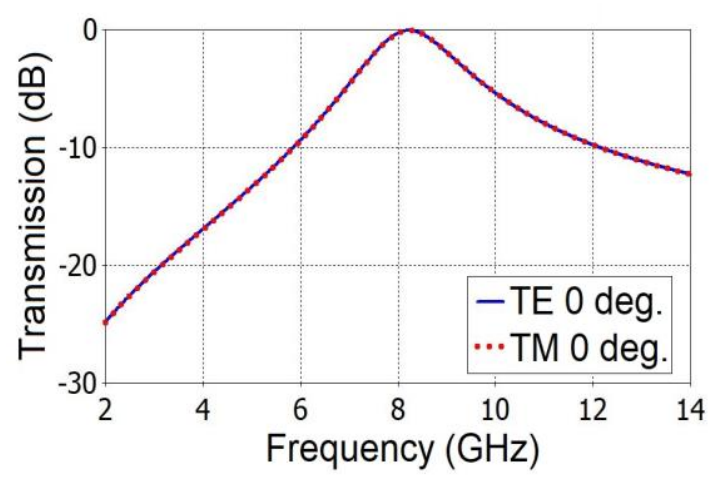

Figure 4. TE and TM polarization comparison at normal incident angle 

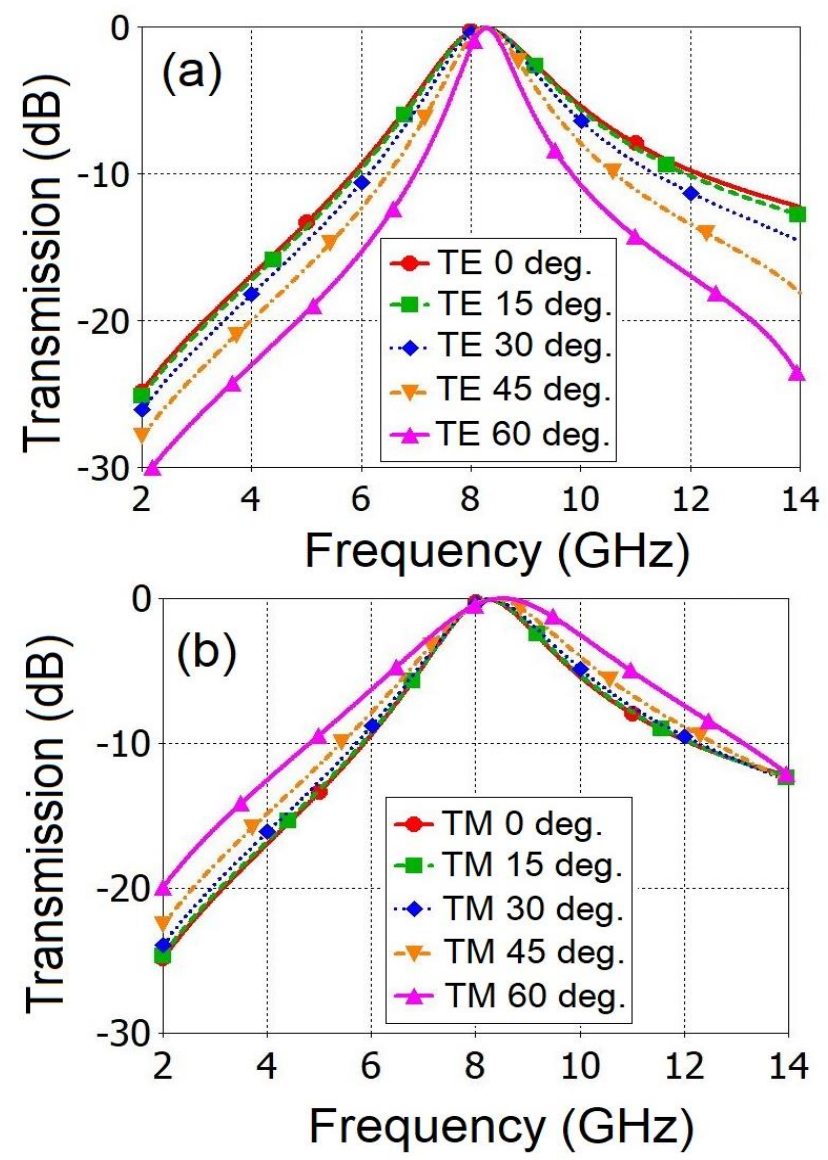

Figure 5. Transmission coefficients of (a) TE and (b) TM polarization under different incident angle

The transmission response has also investigated under different incident angle conditions ranging from $0^{\circ}$ to $60^{\circ}$ for both TE and TM mode as illustrated in Figure 5. The maximum frequency deviation for $\mathrm{TE}$ mode occurs $0.6 \%$ in $60^{\circ}$ of incident angle with $11.5 \%$ of $3 \mathrm{~dB}$ bandwidth of the centre frequency as shown in Figure 5(a). For the TM mode, it arises $3.3 \%$ in $60^{\circ}$ of incident angle with $37.5 \%$ of $3 \mathrm{~dB}$ bandwidth as shown in Figure 5(b).

\section{FABRICATION AND EXPERIMENTAL STUDIES}

The experimental studies of the proposed FSS structure have conducted to prove the numerical results. The prototype of the FSS structure has been fabricated by a single sided FR4 type dielectric material. The manufactured structure is composed of 20x20 unit cells with dimensions of $180 \mathrm{~mm}$ x $180 \mathrm{~mm}$ as shown in Figure 6(a). This prototype is tested by Agilent PNA-L VNA between the frequencies of $3 \mathrm{GHz}$ and $14 \mathrm{GHz}$. Two horn antennas has been used to observe network parameters as demonstrated in Figure 6(b). The distance between the horn antennas and prototype FSS is adjusted by considering the Fresnel region (near field radiative region). This radiative region can be calculated as $2 \mathrm{D}^{2} / \lambda$. D and $\lambda$ represents the largest antenna dimension and wavelength of the central frequency of operating band, respectively.

The numerical and experimental results have been compared for TE and TM mode in Figure 7 and 8, 
respectively. The loss originated from fabrication errors is around $1 \mathrm{~dB}$ both TE and TM polarization mode for $0^{\circ}$ and $60^{\circ}$. The $3 \mathrm{~dB}$ bandwidths of central frequencies in TE mode are about $22 \%$ and $17.5 \%$ for $0^{\circ}$ and $60^{\circ}$, respectively as shown in Figure 7. In TM mode, the bandwidths are about $21.8 \%$ and $29.8 \%$ for $0^{\circ}$ and $60^{\circ}$, respectively as plotted in Figure 8 . The maximum frequency deviations are $0.8 \%$ and $3.4 \%$ for $\mathrm{TE}$ and $\mathrm{TM}$ mode, respectively for incident angle from $0^{\circ}$ to $60^{\circ}$. It can be seen from Figure 7 and 8 that a slight frequency differences which is originated from fabrication and calibration errors were occurred between measured and simulated results. However, the results are in a good agreement with respect angular stability and $3 \mathrm{~dB}$ bandwidth.
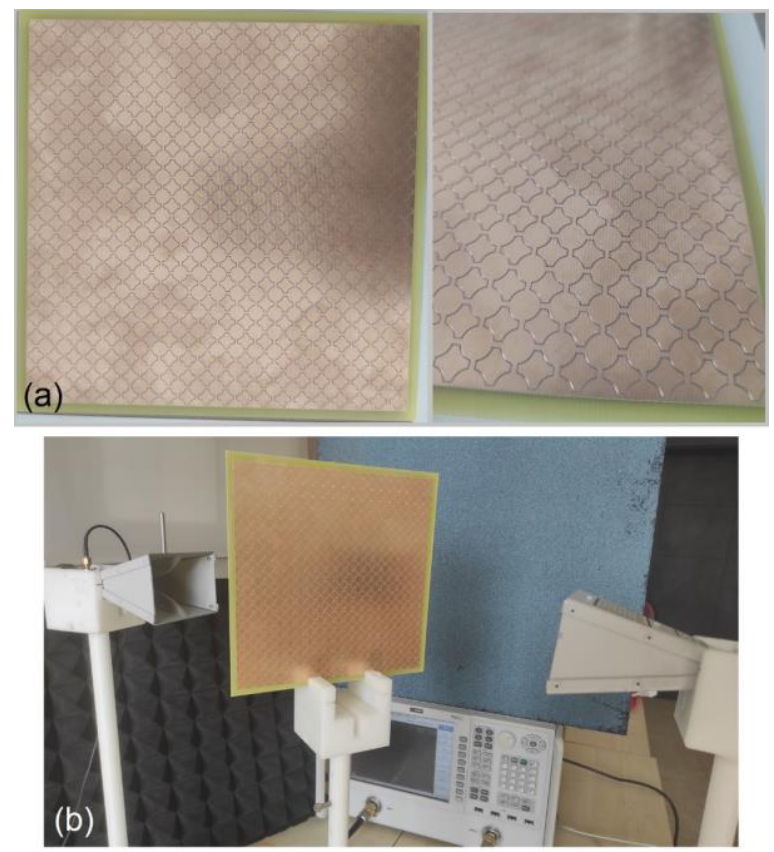

Figure 6. (a) Fabricated prototype of FSS structure and (b) experimental setup

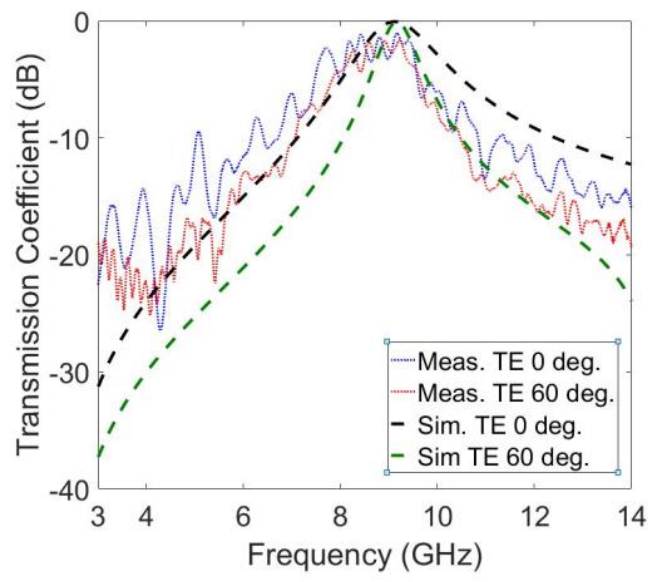

Figure 7. Comparison of simulation and measurement results for TE mode

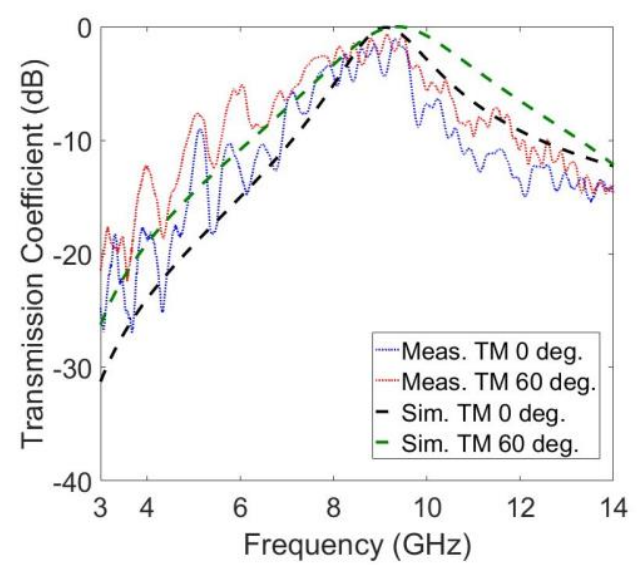

Figure 8. Comparison of simulation and measurement results for TM mode 


\section{CONCLUSION}

In this paper, complementary fractal loop shaped bandpass FSS filter has been proposed for the applications of earth observations satellites and radars. The transmission band of the proposed FSS filter is from $7.3 \mathrm{GHz}$ to $9.3 \mathrm{GHz}$. The FSS filter structure is studied both numerically and experimentally between the frequency ranges between $2 \mathrm{GHz}$ and $14 \mathrm{GHz}$. It has angular stability with small frequency deviation and polarization insensitivity characteristics. The transmission band of the proposed FSS structure contains downlink frequencies of some satellites such as Terra, Aqua, ERS-2, EROS A1, Landsat, and etc. The bandpass FSS structure can be effectively used in these type of satellite systems by preventing noise and undesired frequencies and by improving signal to noise ratio.

\section{REFERENCES}

1. Chou, H.H., Ke, G.J., 2021. Narrow Bandpass Frequency Selective Surface with High Level of Angular Stability at Ka-Band. IEEE Microwave and Wireless Components Letters, 31(4), 361-364.

2. Zhao, Z., Li, J., Shi, H., Chen, X., Zhang, A., 2018. A Low-profile Angle-insensitive Bandpass Frequency-selective Surface Based on Vias. IEEE Microwave and Wireless Components Letters, 28(3), 200-202.

3. Wu, W., Liu, X., Cui, K., Ma, Y., Yuan, Y., 2017. An Ultrathin and Polarization-insensitive Frequency Selective Surface at Ka-band. IEEE Antennas and Wireless Propagation Letters, 17(1), 74-77.

4. Hussein, M., Zhou, J., Huang, Y., Al-Juboori, B., 2017. A Low-profile Miniaturized Secondorder Bandpass Frequency Selective Surface. IEEE Antennas and Wireless Propagation Letters, 16, 2791-2794.

5. Li, H., Yang, C., Cao, Q., Wang, Y., 2016. An Ultrathin Bandpass Frequency Selective Surface with Miniaturized Element. IEEE Antennas and Wireless Propagation Letters, 16, 341-344.
6. Kocakaya, A., Çakır, G., 2018. Novel Angular-independent Higher Order Band-stop Frequency Selective Surface for X-band Applicationsç IET Microwaves, Antennas \& Propagation, 12(1), 15-22.

7. Panwar, R., Lee, J.R., 2017. Progress in Frequency Selective Surface-based Smart Electromagnetic Structures: A Critical Review. Aerospace Science and Technology, 66, 216234.

8. Morrow, I.L., Morrison, K., Finnis, M., Whittow, W., 2015. A Low Profile Retrodirective Frequency Selective Surface for Radar Earth Observation. Loughborough Antennas \& Propagation Conference (LAPC) 1-4, IEEE.

9. Deng, R., Xu, S., Yang, F., Li, M., 2018. An FSS-backed Ku/Ka Quad-band Reflectarray Antenna for Satellite Communications. IEEE Transactions on Antennas and Propagation, 66(8), 4353-4358.

10. Smith, T., Gothelf, U., Kim, O.S., Breinbjerg, O., 2013. An FSS-backed 20/30 GHz Circularly Polarized Reflectarray for a Shared Aperture L-and Ka-band Satellite Communication Antenna. IEEE Transactions on Antennas and Propagation, 62(2), 661-668.

11. Ferraro, A., Zografopoulos, D.C., Caputo, R., Beccherelli, R., 2017. Angle-resolved and Polarization-dependent Investigation of Crossshaped Frequency-selective Surface Terahertz Filters. Applied Physics Letters, 110(14), 141107.

12.Euler, M., Fusco, V., Cahill, R., Dickie, R., 2010. $325 \mathrm{GHz}$ Single Layer Sub-millimeter Wave FSS Based Split Slot Ring Linear to Circular Polarization Convertor. IEEE Transactions on Antennas and propagation, 58(7), 2457-2459.

13. Machado, G.G., Cahill, R., Fusco, V., Conway, G., 2019. Resistively Loaded Ultra-thin FSS Absorbers for Radio-frequency Enhancement of Spacecraft Thermal Blankets. IET Microwaves, Antennas \& Propagation, 13(11), 1928-1933.

14. Raymond, D., Cahill, R., Baine, P., Fusco, V.F., 2018. FSS Design and Manufacturing Challenges for Future Space Science Missions. 
$12^{\text {th }}$ European Conference on Antennas and Propagation (EuCAP 2018) 507-4.

15. Poojali, J., Ray, S., Pesala, B., Chitti, K.V., Arunachalam, K., 2017. Study of Factors Influencing Performance of Substrate Backed FSS for Millimeter Wave Atmopsheric Remote Sensing. $11^{\text {th }}$ European Conference on Antennas and Propagation (EUCAP) 12821286. 